\title{
HISTORIES OF MODERN MIGRATION IN EAST ASIA: STUDIES OF THE FIRST HALF OF THE TWENTIETH CENTURY - CORRIGENDUM
}

\section{Noriaki Hoshino and Qian Zhu}

doi: Io.IoI7/SI47959I4I70000I8 Published online: I2 July 2017

In the above mentioned article [I] the affiliation and email for Noriaki Hoshino were erroneously omitted. This should have been Hong Kong Baptist University, E-mail: noriakih@ hkbu.edu.hk.

\section{REFERENCE}

Hoshino, N. and Q. Zhu. "Histories of Modern Migration in East Asia: Studies of the First Half of the Twentieth Century”. International Journal of Asian Studies I4:2 (20I7), pp. I7 I-95. doi:Io.Ior7/Si47959I4I70000I 8 